\title{
ARTICLE SUMMARIES
}

\section{A "Velvet Prison" with Chinese Characteristics: The Construction of Culture in Post-1989 China | Keith Goodwin}

On June 4, 1989, the Tiananmen Square protests transformed Beijing into a virtual war zone. To many in the West, it seemed that China was on the verge of a dramatic revolution that would see the collapse of communism and the emergence of a democratic China. While there have been many changes in China since 1989, Goodwin argues that post-1989 China has been most visibly defined by a profound tension between the Chinese Communist Party's attempts to foster dramatic economic development and modernization and its desire to avoid challenges to its traditional authority. Building upon Miklós Haraszti's The Velvet Prison: Artists Under State Socialism, Goodwin argues that the state no longer possesses a monopoly on culture in post-1989 China. Although the state has been successful in reinventing its hegemonic structure and has continued to maintain a large degree of control, Goodwin contends that individuals, groups, and the forces of the market economy have also gained an enormous degree of influence in the construction of culture, and have frequently challenged, if not undermined, the Chinese government's traditional authority.

\section{The Housewife's Battle on the Home Front: Women in World War II Advertisements | Caroline Cornell}

In this article, Caroline Cornell analyzes the ways in which American women were portrayed in American media and war advertisements during World War II. As American men left to fight overseas, numerous jobs became vacant, including important factory jobs that were essential to military success. Although many women rose to the task of filling these vacancies, a large portion of women aided the war effort from home. Housewives played a substantial role in the success of wartime rationing and salvaging efforts, the campaign for victory gardens, and the purchasing of 
war bonds. While images such as "Rosie the Riveter" predominate contemporary perceptions of the role of women in the war effort, Cornell argues that advertisements during the period suggest that the housewife was crucially important and well respected during the period, especially as the war started to end.

\section{"The China Lobby": Influences on U.S.-China Foreign Policy in the Postwar Period, 1949-1954 | Jeff Blackwell}

The "China Lobby" was a broad network of people, both foreign and domestic, whose interests coalesced around the goal of overthrowing communism in China following the rise of Mao Zedong. Aided by the anticommunist political environment of 1950s America, the Lobby's loose affiliation of influential individuals-which included well-financed National Chinese officials, right-wing American political elites, and key associates in the private sector and media-exerted considerable pressure on U.S. foreign policy decisions concerning China. Focusing on the period 1949-1954, Blackwell argues that the China Lobby's use of political lobbying, sympathetic media outlets, and attacks on critics of pro-Nationalist policy allowed it to effectively promote a proChiang Kai-shek foreign policy.

Seeing Pennsylvania as the Keystone of the Revolution: Charles $\mathbf{H}$. Lincoln's Treatment of Ethnicity | Greg Rogers

Greg Rogers analyzes Charles H. Lincoln's The Revolutionary Movement in Pennsylvania, 1760-1776, a significant work in the historiography of the American Revolution. According to Rogers, the concept of ethnicity, or “race," permeates Lincoln's 1901 book. Rogers notes, for example, that the development of the American Revolution in Pennsylvania is depicted as being an ethnic struggle in which competing blocs of English Quakers, Scotch-Irish, and Germans struggle for political control amongst themselves as well as the British metropole. In this sense, Lincoln's history marks the first example of the "dual-revolution thesis" later made famous by 
Carl Becker. After analyzing the content, historical context, and subject matter of the monograph, Rogers argues that Lincoln's view of ethnicity and its importance in his work can be attributed not only to the monograph's focus on Pennsylvania, but also to influences of the Progressive Era and its historiographical approach. Whether or not Pennsylvania and Progressive-Era thinking produced a skewed or inaccurate account of the American Revolution is open to debate. What is certain, Rogers concludes, is that factors of contemporary time and provincial place are just as evident in Lincoln's text as the broader thesis he pioneers.

\section{Reading Between the Laws: Literary Representations of the French Homosexual, 1942-1981 | Alison Veith}

It was not until the turn of the twentieth century that the word "homosexual" began to define a person or state of being. Before appearing in medical discourse and the psychoanalytic work of individuals like Sigmund Freud, the word was associated with a sexual act, not as significant aspect of one's identity. Considering this lexical transition and the beginning of homosexual identity articulations in France, Alison Veith explores the ways that the French homosexual male defined himself, how historical, social, and ideological factors influenced that self-definition, and, finally, asks what comparisons might be made between the French homosexual and his American counterpart. Focusing specifically on the period 1942-1981-a period in which anti-gay legislation directly imposed a guise of discretion and invisibility on the developing "gay community" - Veith draws on writings by both French and American homosexual men in Paris, not only in order to compare their national and cultural perspective, but to better understand their sense of personal identity, personal sexuality, and personal nationality. 
An America that Could Be: Emma Goldman, Anarchism, and the “American Dream”| Christina Samons

The so-called "Gilded Age," 1865-1901, was a period in American history characterized by great progress, but also of great turmoil as the United States underwent social, economic, and political transformations. Out of this period emerged Emma Goldman, who, responding to the transformations of the Gilded Age, became a well-known critic of both governmental and non-governmental institutions and a controversial advocate of anarchism in the early twentieth century. In this article, Christina Samons analyzes primary sources written by Goldman in order to explain the salient features of her anarchist theory. In doing so, she attempts to reconcile Goldman's insistence on a return to the ideals set forth during the American Revolution with the historical environment in which Emma Goldman wrote. In Goldman's opinion, Samons argues, American society had drifted away from the ideal of the "American Dream" due to the institutionalization of exploitation within all aspects of social and political life: namely economics, religion, and the law.

\section{In Defense of Southern Honor: Preston Brooks and the Attack on Charles Sumner | Daniel Lawrence Slusser}

On May 22, 1856, South Carolina Congressman Preston Brooks approached the desk of Massachusetts Senator Charles Sumner. Declaring Sumner's recent speech to be a "libel on South Carolina," Brooks proceeded to brutally attack Sumner with his cane. Looking back on this incident, Daniel Lawrence Slusser examines the personal and political circumstances leading up to the attack on Sumner as well as the cultural forces that shaped Preston Brooks's personal psychology. Ultimately, Slusser argues, Brooks's attack on Sumner was representative of culture in the antebellum South and its fixation on the cause of honor-a mentality that would also be influential in the build-up to the Civil War. 